\title{
The abduction of Sherlock Holmes
}

\author{
David Carson \\ Institute of Criminal Justice Studies, University of Portsmouth, St George's Building, \\ 145 High Street, Old Portsmouth, PO1 2HY. Tel: 07971 843243; email: \\ David.Carson@port.ac.uk
}

Received 29 February 2008; accepted 9 July 2008

Keywords: crime investigation, inferential reasoning, deduction, induction, abduction, police training

David Carson is Reader in Law and Behavioural Sciences at the Institute of Criminal Justice Studies, University of Portsmouth.

\begin{abstract}
All criminal investigations, and resulting trials, rely upon inferential reasoning. Theories, hypotheses and conclusions, are drawn from the evidence. The victim's blood was on the knife; we infer it was the murder weapon. The suspect's fingerprints are on the knife; we infer he killed the victim. Sherlock Holmes, although a fictional character, remains renowned as a great detective. However, his methodology, which was abduction rather than deduction, and which is innocently used by many real detectives, is rarely described, discussed or researched. This paper compares and contrasts the three forms of inferential reasoning and makes a case for articulating and developing the role of abduction in the work, and training, of police officers.
\end{abstract}

\section{INTRODUCTION}

Sherlock Holmes is renowned as a great detective; indeed the paradigm (Risinger, 2006). His particular skills are said to have been in deduction. But that is false - and not just because he was the fictional creation of Sir Arthur Conan Doyle (Conan Doyle, 1982). Holmes' distinctive investigative skills involved abduction (Anderson,
Schum, \& Twining, 2005, p. 58). This paper will explain abductive inferential reasoning, contrasting it with deduction and induction. It will highlight its importance for what is coming to be known as 'the investigative mindset' (National Centre for Policing Excellence [NCPE], 2005). (That document was approved by the Association of Chief Police Officers (ACPO).) It will be argued that a richer understanding of abduction could enhance the quality of investigations by helping investigators to generate more and better hypotheses, make them more sensitive to potential errors in perception, comprehension and construction, and inhibit premature decisionmaking, which has been associated with a number of improper convictions (Maguire, 2003; Maguire \& Norris, 1992).

Whilst links have been made with the ideas of Aristotle - because he distinguished between the form and the content of an argument (Schum, 1994, p. 23) - the development of abduction is usually associated with American philosopher and polymath, Charles Sanders Peirce (1839-1914). Although they were contemporaries, there is no suggestion that Conan Doyle (1859-1930) took his methods from, or even knew of, Peirce (Anderson et al., 2005). Rather Conan Doyle based Holmes' methodology on that of one of his lecturers, Dr Joseph Bell (1837-1911), Professor of
International Journal of Police Science and Management, Vol. 11 No. 2, 2009, pp. 193-202. DOI: $10.1350 /$ ijps.2009.11.2.123 
Surgery in the Faculty of Medicine at the University of Edinburgh. Bell was renowned (Liebow, 1982) for his ability to infer extensive and particularistic information about his patients, before taking a medical history.

Conan Doyle also used the methodology himself. Amongst some 28 cases with which he was involved (Costello, 1991), Conan Doyle campaigned to get a pardon and compensation for George Edalji, a solicitor who was imprisoned for mutilating horses (Risinger, 2006; Weaver, 2006). Risinger argues that the Edalji case was one of three which led to the creation of the (as then titled) Court of Criminal Appeal, by the Criminal Appeal Act 1907. Julian Barnes' critically acclaimed 'novel' Arthur \& George (2005) (shortlisted for the Man Booker prize) uses that case to provide 'biographies' of both Edalji and Conan Doyle. Whilst criticised for factual errors (Risinger), particularly in comparison with an alternative analysis (Weaver), Barnes highlights the issues. How, for example, did Conan Doyle know, better than the prosecutors and jury, that Edalji was actually innocent?

\section{INFERENTIAL REASONING}

It is impossible to undertake any (criminal) investigation, let alone prove allegations in court, without adopting inferential reasoning. We infer further knowledge from that which we already possess (or believe we possess). Blood has poured from a wound on the corpse. There is a bloody knife lying nearby. We infer that the knife was used to make the wound. The interviewee's manner changes when a particular topic is raised. We infer that he or she is anxious about discussing that topic. Joe Bloggins has a criminal record for committing burglaries where access to the premises was gained via a toilet window. Access was gained via a toilet window in this case. Therefore Joe Bloggins is a suspect. Indeed this inference, that people convicted of committing a crime in a distinctive manner would commit further crimes in that particular way, was allowed to be an exception (the similar facts rule) to the principle that a defendant's prior convictions were inadmissible in evidence (Roberts \& Zuckerman, 2004). (The rule has been subsumed in changes made, for England and Wales, by the Criminal Justice Act 2003.)

There are three, broad forms of inferential reasoning; deduction, induction and abduction. A historical 'development' can be identified. Deduction was the paradigm in medieval trials. Rules, which were assumed to be correct (eg trial by ordeal or the number, rather than quality, of witnesses (Schum, 1994)), were applied. Induction became the current paradigm as science superseded superstition (Jackson, 1988; Schum). But, even though it is now widely accepted that science is dependent upon interpretation (eg re atomic physics, see Bizony, 2007), which is the basis for abduction, we have yet to acknowledge that within our trial systems. Damaska, the leading scholar of comparative legal systems, has predicted:

As science continues to change the social world, great transformations of factual inquiry lie ahead for all justice systems. These transformations could turn out to be as momentous as those that occurred in the twilight of the Middle Ages, when magical forms of proof retreated before the prototypes of our present evidentiary technology. (Damaska, 1997, p. 151.)

\section{Deduction}

Deduction is distinctive in that, if the premises are true and the correct processes are adopted, we can be certain that the conclusions are correct. That is because deduction involves no more than discovering the implications of what we already know. The syllogism is the paradigm form of deductive 
reasoning. All collies are dogs; Rover is a collie, therefore Rover is a dog. We learn the implications of Rover being a collie. Fingerprints are unique; therefore this suspect, whose fingerprint is on the murder weapon, must have handled it. This sort of reasoning is very seductive. The explicit or implicit use of general, categorical, definitional or similar all-encompassing expressions (eg 'all collies' or even just 'fingerprints', as it implies all of them), followed by 'therefore', or a comparable expression, gives an impression of the conclusion being logical, inevitable, necessary. It is what we want in our criminal trials; all people who do $\mathrm{X}$ are guilty; the defendant did X, therefore the defendant is guilty. Thus it is understandable that Sherlock Holmes' intellect and prowess, when associated with this deductive method, should be celebrated. But his method was not deductive.

Deductive reasoning, when properly used (Kelley, 1994), tells us no more than what is already known.

[A] deductive conclusion contains nothing that is not already included in the premises. (Anderson et al., 2005, p. 56).

Provided that the general rule, definition, category, etc, is correct, and the correct rules of reasoning ('syntax', Robertson, 1999) are used, the conclusion follows. But those are major provisos! Deductive reasoning can only be of limited value to investigators. Critically, there are few major premises, the 'all statements', upon which investigators can rely. Even fingerprints may not be unique (Freckelton \& Selby, 2005; Stoney, 2002).

And the correct rules of reasoning may not be followed. It would, for example, be wrong to confuse major and minor premises to reason that as all collies are dogs, and Rover is a dog, so Rover must be a collie.

The great attraction of deductive reasoning (which contrasts with inductive and abductive) is the potential for conclusions which are necessarily correct. So it is hardly surprising that we often slip into forms of reasoning and argument that have the appearance of deductive reasoning. Generalisations get treated as rules or premises. So it may be declared that: 'People who do not look you in the eye are dishonest. The suspect did not look me in the eye. Therefore he is dishonest.' Such generalisations are, as Schum (1994) has put it, the 'glue' which holds arguments about facts and evidence together. But they are particularly dangerous in legal contexts (Twining, 1999; Anderson et al., 2005). So, contrary to the impression generated by Sherlock Holmes novels, investigators may need to know more about the misuse, than use, of deductive reasoning in investigations.

\section{Induction}

If deduction is most closely associated with logic and philosophy, induction is associated with the physical sciences, particularly in their aspirations to methodological rigour. Deduction, since it involves drawing out the implications of what we already know, does not generate new knowledge. Induction, however, does create more knowledge - but not necessarily correct conclusions.

Today we use the term induction to refer to reasoning that provides only some but not complete grounds for a conclusion. (Schum, 1994, p. 24)

We observe a number of instances, for example the frequency with which people who have been reported as missing return home within 72 hours; that violence and alcohol often co-occur; that several women do not leave their abusive partners. We make links; we infer, we draw conclusions and start generalising. Some of these observations, conclusions and generalisations are very powerful, in the sense that the frequency of their occurrence is high. Scientific methodology focuses on assuring the 
reliability of those observations. We then use, explicitly and implicitly, those observations to make causal connections, both to predict and to explain. But, since they are inductive rather than deductive, they are not necessarily correct; reliability is not the same as certainty. Their accuracy and reliability depend upon the quality of the methodology adopted.

Inductive reasoning is very easy to do we all do it without any training - but it is difficult to do well. It is open to many sources of error. Prejudices and biases regularly arise from inappropriate inferences from inductive knowledge. If we only notice, or attend to, risk decisions where harm results, then we will have incomplete knowledge leading to poor decisions, or inferences, in the future (Carson \& Bain, 2008). The 'availability heuristic' refers to the common error whereby decisionmakers, including investigators (Ask \& Granhag, 2005), rely on existing information rather than seek further evidence or qualify their decisions. To a considerable extent, but not always sufficiently or appropriately, we assess the reliability of our inferences by the degree of scientific rigour involved. Thus 'forensic science' evidence, particularly that relating to DNA, is highly regarded, although errors have been made in drawing inferences from the data (Balding \& Donnelly, 1994).

Inductive reasoning, with its links to empiricism and scientific method, tends to be positivist. It accepts (or does not challenge the assumption) that facts exist independent of observation; that observers can see, hear or otherwise sense data without affecting them. 'The observed man was shaven, alone, large and threatening.' Some expressions are too broad; we need to have a range of words to encompass matters of degree, such as 'large'. But that is a language problem; provided the witness is competent and truthful, the facts exist, and the only problem is finding the best verbal description. Abduction disagrees.

\section{Abduction}

Abduction involves interpretative epistemologies which insist that 'facts' cannot be understood independent of how we observe and understand them. Abduction emphasises that, when we perceive something, we interpret it. It is not just a problem in finding the right word. Even without realising it, we 'make sense' of what we have observed or experienced. We find a dead dog on a road and, nearby, skid marks ostensibly from a car. We infer that the dog ran out into the road, the car driver tried to avoid it but, skidded, hit and killed it. We may be right. We may have consciously thought the inference through, or just 'jumped' to that conclusion. Further knowledge, for example finding a car with damage consistent with hitting such a dog and hairs matching the particular dog's attached to it, would make our interpretation, our abduction, more credible or powerful. Learning that the skid marks are a week old would undermine it.

Burks (1946) argues that Peirce saw the three systems of inferential reasoning as stages in an enquiry. All are related to hypotheses, as are criminal investigations. Abduction creates the hypothesis, for example that this particular knife was used to kill that victim. Induction tests that theory; forensic tests may allow a qualified person to confirm that hypothesis. And deduction allows us to work out the necessary consequences of those inferences, if the premises produced are true.

Abduction is the process of forming an explanatory hypothesis. It is the only logical operation which introduces any new idea; for induction does nothing but determine a value, and deduction merely evolves the necessary consequences of a 
pure hypothesis. (Peirce, quoted in Burks, p. 303)

Peirce also associated abduction with those sudden insights (hypotheses) when we, unexpectedly, get an idea which solves, or appears to solve, a problem we had not previously managed to solve (Burks; Schum, 1994). The abductive inference covers, or explains, at least some of the information we currently have.

Sherlock Holmes was skilled at abduction.

... I see Holmes as the first modern superhero, and the first great literary superhero since King Arthur or Robin Hood, but with a difference. Holmes was a superhero of the mind. (Risinger, 2006, p. 5)

He was particularly skilled because his insights were invariably shown to be correct (as Conan Doyle ensured). In A Study in Scarlet (Conan Doyle, 1982) Holmes attributed his competence to a rare ability 'to reason backwards', to explain what had happened, rather than forwards ('synthetically'), to predict what would happen, the practice of 'normal' people. Julian Barnes (2005) suggests that Conan Doyle concluded that George Edalji was innocent because the latter had an obvious eye defect.

A man's virtues are turned into faults. Self-control presents itself as secretiveness, intelligence as cunning. And so a respectable lawyer, bat-blind and of slight physique, becomes a degenerate who flits across fields at dead of night, evading the watch of twenty special constables, in order to wade through the blood of mutilated animals. It is so utterly topsyturvy that it seems logical. And in Arthur's judgment, it all boiled down to that singular optical defect which he had immediately observed in the foyer of the Grand Hotel, Charing Cross. Therein lay the moral certainty of George Edalji's innocence, and the reason why he should have become a scapegoat. (Barnes, 2005, p. 234) (emphasis added)

Given the emphasis upon the interpretation of the signs available - which is the science of semiotics - it is unfortunate (in one sense) that the book was not written by the novelist and semiologist, Umberto Eco.

Barnes suggests that Conan Doyle was able to produce, by abduction, a more complete and accurate interpretation of the existing facts. Significantly, he focused on less evidence, the eye defect, interpreting it as being so powerful as to make the other evidence, collected by the police, irrelevant. In the extract quoted, Barnes suggests this required/enabled him to reverse the inferences that the police had drawn. George Edalji's eyesight problems, his social isolation, his apparently strange behaviour, and very likely his colour and ethnic origin, suggested criminality to the police. These may be considered incorrect generalisations, bias or prejudice. Conan Doyle had the intellectual courage to reverse the inferences which had led the police to Edalji. But Conan Doyle's 'abduction' may better be understood as a perceptual judgement (Schum, 1994), particularly as his medical speciality had been ophthalmology. He was able to draw upon his specialist knowledge, that people with George Edalji's eyesight problems could not do the kinds of things alleged, particularly in the dark. But that is an induction; it involves inferring from existing knowledge. It was not a creative interpretation of the facts.

A more dramatic example, of the dangers of misuses of inferential reasoning, occurred during Edalji's trial. The animal mutilations had continued, even whilst Edalji was imprisoned awaiting trial. Edalji appears to have hoped that the 'obvious' inference 
would be drawn; the police had the wrong person. But the prosecutor used his skills in advocacy to turn that inference on 'its head'. He suggested that Edalji was a member of a gang (although there was no evidence of this), which mutilated animals. That Edalji had declined bail demonstrated that he knew the mutilations would continue so that he could - falsely — claim that he was innocent! (Another novel might be suggested, Joseph Heller's Catch-22.)

\section{IMPLICATIONS OF ABDUCTION}

Nordby (2000) has exemplified the centrality of abduction to the work of forensic scientists, and Innes (2003) to that of detectives. Innes observed English detectives working on five active murder inquiries, and analysed 20 completed murder inquiries along with 50 other investigations. He concluded that abduction was ' $[\mathrm{b}] \mathrm{y}$ far the most commonly deployed form of investigative logic employed on murder enquiries ...' (Innes, p. 184).

It is a creative form of sense-making interpretative inference, wherein the presence of a fact is used to generate an explanation for its causes... In a sense, then, crime investigation practice is founded upon the abductive interpretation of various signifiers and can thus be constructed as a situated and stylized form of applied semiotic analysis. (Innes, p. 179)

However, he notes that:

The particular difficulty of abductive reasoning in detective work is the slight tendency for consequent factors to be interpreted in such a way that their inferred antecedents are assimilated by the current dominant hypothesis held by the police about the crime. (Innes, p. 185)
But that would not be abduction. Those detectives would be trying to fit the fresh information into the current theory of how and why the crime was committed. They would be testing that hypothesis, rather than generating a fresh one. Unless the exercise involves a reinterpretation of all or part of what is known, it would not include the critical creative character of abduction.

To reduce the possibility of 'case construction' (Maguire, 2003; Maguire \& Norris, 1992) or 'premature decisionmaking' (Carson, 2007), detectives should be encouraged to develop competing abductive explanations for comparative assessment. Innes (2003) notes that 'forensic science' evidence is regularly considered to be 'hard evidence' and often accorded a status of being all but beyond criticism or doubt. However, forensic traces are obtained outside controlled laboratories. As such, they are at risk of being altered, affected or interfered with, even though the maintenance of a secure scene of crime is given the highest priority in policing manuals (NCPE, 2005). Further, the police regularly provide forensic scientists with background information which, unsurprisingly, influences their interpretations of what must/may have happened. Consequently, forensic scientists are liable to reason, inductively, on hypotheses that have been suggested to them rather than develop their own abductive inferences. That could put them in breach of their duties as expert witnesses ( $R$ v Bowman [2006] EWCA Crim 417).

The NCPE's practical guidance on the core investigative doctrine (which does not mention 'abduction'), recognises that flawed decision-making has caused several failed investigations and miscarriages of justice. It notes that:

Relatively little research has been conducted into ways in which investigators make decisions. (p. 58) 
(See also Innes, 2007; Tong \& Bowling, 2006.) It encourages the use of an 'investigative mindset'.

There is no process map that will assist the investigator to develop the mindset, it is a state of mind or attitude which investigators adopt and which can be developed over time through continued use. It involves applying a set of principles to the investigative process. This will enable investigators to develop a disciplined approach which assures that the decisions they make are appropriate to the case, are reasonable and can be explained to others. (NCPE, p. 60)

It breaks the mindset down into five principles, which have more to do with good ways of acting (eg appreciating the provenance of evidence, getting the most possible from the first examination of the crime scene, etc), rather than any attitude or state of mind. Investigators are encouraged to use the $\mathrm{ABC}$ approach: assume nothing, believe nothing, challenge everything (p. 62). That might assist in encouraging a critical attitude towards information provided. It should encourage a focus on the provenance of facts which might encourage thinking about the inferences that are drawn from them. But it is unrealistic, and illogical, in that assumptions and beliefs have to develop if any hypothesis or theory is to develop.

A richer understanding of abduction, as a dialectical device for generating critical and creative hypotheses which focus attention on the nature and quality of the inferential reasoning being used, might help to flesh out the concept of an investigative mindset. The NCPE (2005) is right to insist that '[i]nvestigators should ... continually challenge the meaning and the reliability of any material they gather' (p. 62), but individuals may be reluctant to do so, and hierarchical working relations may dissuade them. A Swedish study revealed that experienced police investigators were less sensitive than university students to alternative hypotheses for how and why a crime was committed (Ask \& Granhag, 2005). One potentially very rewarding way forward would be to incorporate the practical work of some of the New Evidence Scholars (eg rewriting NCPE's (2005) practical advice in the light of the rich set of ideas in Chapters 2 and 3 of Anderson, Schum and Twining (2005)). Lawyers may not have a long history of identifying and analysing facts, but they do with regard to issues of inference and problems of proof (Anderson et al., 2005; Schum, 1994). Those skills could be honed. Further, the meaning of 'facts' is not given; the science of semiotics has developed to investigate the processes whereby signs are interpreted. This has manifest relevance to police investigations (Innes, 2003; Schum, 1994). The imagination needed for contemplating alternative scenarios is not a given. Do the employment conditions of detectives and other investigators reward or discourage abduction? It is natural (and often appropriate) to be irritated by people who insist on offering alternative ideas, thereby slowing down and making decision-making processes more fraught and resource intensive.

\section{CONCLUSION}

Abduction is little understood and almost never mentioned in the policing and investigations literature. It is not mentioned (other than as a type of crime) in Smith and Flanagan's (2000) review of the skills required by effective detectives. To the extent that their methodology involved asking current officers to identify the skills of an effective detective, this is not surprising, nor a criticism. Abduction is not a commonplace term for investigators to use, 
or to reflect upon, even if it is commonplace to their repertoire of methods (Innes, 2003). However, it relates to several of the headings recognised under 'investigative ability'.

Five skill areas were classified under the heading of investigative ability: investigative competence; appraisal of incoming information; adaptation; strategic awareness; and, innovative investigative style. (Smith and Flanagan, p. 26)

It also relates to detectives' valuation of 'slow time', that is time to reflect (Smith \& Flanagan, p. 30). Investigators should be encouraged to be more aware of their thinking styles, and reflective of the ways in which they hypothesise about how offences took place.

Three developments are essential. First, respect for 'healthy scepticism' (Grieve, Crego, \& Griffiths, 2007) needs to be guaranteed within organisations. Abduction is only 'safe' and possible where investigators know that they are permitted and encouraged to think differently, although that will often be interpreted as being 'awkward'. The current emphasis in the management of police investigations is on performance, on products rather than processes (Neyroud \& Disley, 2007). The current emphasis in identifying and teaching investigative skills is on the behavioural and inter-personal skills rather than the cognitive (Grieve et al., 2007; NCPE, 2005; Smith \& Flanagan, 2000). These emphases need to be corrected.

Attention also needs to be paid to the grave risk of 'intelligence' being bureaucratised. Attention should be focused on how ideas are generated, not just how they are generalised down the line to those who appear not to be trusted to do too much thinking for themselves, or not having any discretion to act differently. This is not an attack on police forces, who have demonstrated considerable willingness to change (Neyroud \& Disley, 2007), as it also happens in many other institutions including universities, which are supposed to be havens of critical, challenging and alternative thinking. (See Power (2004) on how creativity and excitement can get reanalysed into a risk that needs to be managed.) Savage and Milne (2007) wonder whether there is a danger in linking detective work with 'creativity' in that it will reinforce an image of the job being about 'art' or craft (p. 625). They suggest a quasi-scientific model. However, Tong and Bowling (2006) identified 'art,' alongside 'craft' and 'science' in their model of police investigators' skills. If the 'art' is understood as requiring knowledge of, and skills in, epistemology and reasoning, then, it is submitted, detectives should be proud of and motivated by their creative duties.

Second, the nature of abduction needs to be developed; it needs extensive elaboration, explanation, exemplification and research. That would be entirely consistent with, and supportive of, the steps being taken to professionalise investigative practice (Stelfox, 2007). It could be incorporated into the 'investigative mindset' (NCPE, 2005). But it should also feature prominently in basic training, with a view to encouraging 'good thief takers'. Some officers are, for example, skilful in identifying suspicious people or circumstances, without understanding their methods. (A future paper will identify possible contents of courses designed to encourage abductive reasoning.) Third, abduction needs to be seen in the context of inferential reasoning about proof as well as investigation. It is not suggested that abductive reasoning is, let alone that adversarial trials are, superior to inductive reasoning or investigatory trials. Nor is it suggested that one could or should replace the other. Their differences and comparative strengths should be recognised 
and regarded as complementary. It is perfectly natural that the many sciences and disciplines involved (eg computer sciences (artificial intelligence applications), decision-making sciences, forensic sciences, law (eg New Evidence Scholarship), philosophy, policing, psychology, etc) will continue to develop in their separate journals, books, conferences and forms of 'silos', but time and space needs to set aside for a multidisciplinary 'science of investigations'.

After all, as Sherlock Holmes said to Dr Watson, in A Study in Scarlet:

They say that genius is an infinite capacity for taking pains, ... It's a very bad definition, but it does apply to detective work. (Conan Doyle, 1982, p. 31)

\section{References}

Anderson, T., Schum, D., \& Twining, W. (2005). Analysis of Evidence (2nd ed.). Cambridge: Cambridge University Press.

Ask, K., \& Granhag, P. A. (2005). Motivational sources of confirmation bias in criminal investigations: The need for cognitive closure. Journal of Investigative Psychology and Offender Profiling, 2, 43-63.

Balding, D. J., \& Donnelly, P. (1994). The prosecutor's fallacy and DNA evidence. Criminal Law Review, 711.

Barnes, J. (2005). Arthur \& George. London: Jonathan Cape.

Bizony, P. (2007). Atom. Thriplow (Cambs.): Icon Books.

Burks, A. W. (1946). Peirce's theory of abduction. Philosophy of Science, 13(4), 301-306.

Carson, D. (2007). Models of Investigation. In T. Newburn, T. Williamson, \& A. Wright (Eds.), Handbook of Criminal Investigation (pp. 407-425). Cullompton (Devon): Willan.

Carson, D., \& Bain, A. J. (2008). Professional Risk and Working with People. London: Jessica Kingsley Publishers.
Conan Doyle, Sir A. (1982). The Penguin Complete Sherlock Holmes, London: Penguin.

Costello, P. (1991). The Real World of Sherlock Holmes: True Crimes Investigated by Arthur Conan Doyle. New York: Carroll \& Graf.

Damaska, M. R. (1997). Evidence Law Adrift. New Haven: Yale University Press.

Freckelton, I., \& Selby, H. (2005). Expert Evidence: Law, Practice, Procedure and Advocacy (3rd ed.). Sydney: Thomson.

Grieve, J., Crego, J., \& Griffiths, B. (2007). Critical incidents: Investigation, management and training. In T. Newburn, T. Williamson, \& A. Wright (Eds.), Handbook of Criminal Investigation (pp. 572-583). Cullompton (Devon): Willan.

Innes, M. (2003). Investigating Murder: Detective Work and the Police Response to Criminal Homicide. Oxford: Oxford University Press.

Innes, M. (2007). Investigation order and major crime inquiries. In T. Newburn, T. Williamson, \& A. Wright (Eds.), Handbook of Criminal Investigation (pp. 255-276). Cullompton (Devon): Willan.

Jackson, J. D. (1988). Two methods of proof in criminal procedure. Modern Law Review, 51(5), 549-568.

Kelley, D. (1994). The Art of Reasoning (2nd ed.). New York: W. W. Norton.

Liebow, E. (1982). Dr Joe Bell: Model for Sherlock Holmes. Bowling Green: Bowling Green University Popular Press.

Maguire, M. (2003). Criminal investigation and crime control. In T. Newburn (Ed.), Handbook of Policing (pp. 363-393). Cullompton (Devon): Willan.

Maguire, M., \& Norris, C. (1992). The Conduct and Supervision of Criminal Investigations. (Royal Commission on Criminal Justice, Research Study No. 5.). London: HMSO.

National Centre for Policing Excellence. (2005). Practice Advice on Core Investigative Doctrine. Centrex, Association of Chief Police Officers (no place of publication provided).

Neyroud, P., \& Disley, E. (2007). The management, supervision and oversight of criminal investigation. In T. Newburn, T. Williamson, \& A. Wright (Eds.), Handbook 
of Criminal Investigation (pp. 549-571). Cullompton (Devon): Willan.

Nordby, J. J. (2000). Dead Reckoning: The Art of Forensic Detection. Boca Raton, FL: CRC Press.

Power, M. (2004). The Risk Management of Everything: Rethinking the Politics of Uncertainty. London: Demos.

Risinger, D. Michael (2006). 'Boxes in Boxes: Julian Barnes, Conan Doyle, Sherlock Holmes and the Edalji Case,' International Commentary on Evidence: Vol. 4: Iss. 2, Article 3. Accessed 10 January 2008 at http://www.bepress.com/ice/vol4/iss2/art3

Roberts, P., \& Zuckerman, A. (2004). Criminal Evidence. Oxford: Oxford University Press.

Robertson, S. I. (1999). Types of Thinking. London: Routledge.

Savage, S. P., \& Milne, R. (2007). Miscarriages of justice. In T. Newburn, T. Williamson, \& A. Wright (Eds.), Handbook of Criminal Investigation (pp. 610-627). Cullompton (Devon): Willan.

Schum, D. A. (1994). Evidential Foundations of Probabilistic Reasoning. New York: Wiley.
Smith, N., \& Flanagan, C. (2000). The Effective Detective: Identifying the Skills of an Effective SIO (Police Research Series Paper 122). London: Home Office.

Stelfox, P. (2007). Professionalizing criminal investigation. In T. Newburn, T. Williamson, \& A. Wright (Eds.), Handbook of Criminal Investigation (pp. 628-651). Cullompton (Devon): Willan.

Stoney, D. A. (2002). The scientific basis of expert testimony on fingerprint identification. In D. L. Faigman, D. H. Kaye, M. J. Saks, \& F. Sanders (Eds.), Science in the Law: Forensic Science Issues (pp. 82112). St Paul, MN: Thomson.

Tong, S., \& Bowling, B. (2006). Art, craft and science of detective work. Police Journal, 79, 323-329.

Twining, W. (1999). 'Narrative and generalizations in argumentation about questions of fact.' South Texas Law Review, 40, 351-365.

Weaver, G. (2006). Conan Doyle and the Parson's Son: The George Edalji case. Cambridge: Vanguard Press. 